KAWISTARA

VOLUME 3

No. 2, 17 Agustus 2013

Halaman 117-226

\title{
PEREMPUAN DAN NEGARA: KAJIAN FEMINIS DALAM KONTEKS SOSIAL “BH” KARYA AGUS NOOR
}

\author{
Chris Woodrich \\ Fakultas Ilmu Budaya Universitas Gadjah Mada \\ Email: chris_woodrich@hotmail.com
}

\begin{abstract}
The struggle of the oppressed to obtain their rights is never complete. There is always someone who is

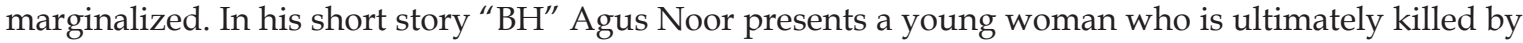
her bra, a garment which had repeatedly groped her breasts previously. At the surface this unrealistic story appears to be a simple critique against the repression of women. However, when placed against the socio-political backdrop in which it was written, namely that of the repressive New Order government under President Suharto, it is readily apparent that the oppression of women is used as a symbol of the general oppression and censorship in New Order Indonesia. In the New Order, as presented by Agus Noor, the aged (and thus empowered) forces used a familial form of "anakisme" to subjugate the general populace and thus ensure that the general populace cannot efficiently overturn the power structure. This reading reminds us that women's struggle for recognition and equality cannot be divorced from the struggles of other oppressed classes, which must fight for their rights and often collaborate for a greater effect.
\end{abstract}

Keywords: Agus Noor, BH, New Order (Criticism of), Censorship, Feminism

\begin{abstract}
ABSTRAK
Perjuangan orang tertindas untuk mendapatkan hak mereka dengan semestinya tak pernah selesai. Masih ada yang dinomorduakan yang tidak diperlakukan seperti orang lain. Dalam cerita pendeknya "BH", Agus Noor menceritakan seorang perempuan yang akhirnya mati karena kutangnya, yang suka meraba-raba payudaranya. Cerita yang tidak realistis ini, kelihatan di permukaan sebagai kritik terhadap opresi perempuan belaka. Namun, setelah melacak peristiwa sosial yang dikritik dengan membongkar simbol-simbol yang ditawarkan dalam cerita, nampak jelas bahwa opresi perempuan digunakan sebagai gambaran dari opresi masyarakat umum selama pemerintahan Suharto. Pada periode ini, pemerintah membangun suatu sistem kekeluargaan yang menempatkan pihak-pihak yang dipertua(n)kan sebagai orang tua (yang wajib dihormati) dan masyarakat awam sebagai anak (yang wajib menuruti). Hal ini menyadarkan kita kembali bahwa perjuangan perempuan tidak terlepas daripada perjuangan masyarakat tertindas lainnya, yang sama-sama memperjuangkan hak mereka dan bahkan perlu bekerja sama demi hal itu.
\end{abstract}

Kata kunci: Agus Noor, BH, Kritik Orde Baru, Penyensoran, Feminisme 


\section{PENGANTAR}

Pembahasan mengenai karya sastra Indonesia yang menggunakan teori feminis biasanya hanya terbatas pada oposisi gender perempuan dan laki-laki, tanpa menghiraukan peranan aspek sosio-budaya lain. Misalnya, Anita K. Rustapa dalam bukunya mengenai Layar Terkembang dan Pada Sebuah Kapal, hanya melihat gagasan mengenai perempuan dan laki-laki (Rustapa, 1997: 5). Demikian pula artikel U'um Qomariyah (2011) mengenai Perempuan Berkalung Sorban, yang sekali lagi menempatkan perempuan sebagai pihak yang selalu dinomorduakan karena pengaruh patriarki, dan tidak melihat hierarki kekuasaan lain. Pemahaman sedemikian rupa dapat dipahami jika arti kata "feminisme" sendiri. Kata feminisme terdiri dari dua unsur, yaitu dasar femin-, yang berasal dari kata Latin fémina (perempuan) dan isme yang berasal dari bahasa Yunani ismos dan mengacu (antara lain) pada suatu sistem kepercayaan atau ilmu. Dengan demikian, feminisme diartikan sebagai ilmu atau kepercayaan mengenai perempuan.

Melalui tafsir feminis yang kerap digunakan dalam analisis di Indonesia, hubungan perempuan dan laki-laki seakan menjadi mutlak, hal yang berdiri dengan sendirinya dan terpisah dari pola lain yang berkembang dalam masyarakat. Seakan lakilaki selalu yang berkuasa, perempuan yang selalu lemah, tidak terkecuali laki-laki miskin dan perempuan kaya. Namun, tafsir ini terlalu sederhana. Selain keberadaan perempuan yang tidak homogen (yang sudah dijelaskan dengan baik oleh Mohanty (1988), pengertian feminisme sebagai teori yang hanya terbatas pada gender saja tidak memperhitungkan kemungkinan adanya aspek sosial lain yang mempengaruhi kedudukan orang atau kelompok tertentu dalam hierarki kekuasaan sehingga pembahasan sedemikian rupa tidak dapat menjelaskan pola-pola kekuasaan riil dalam karya.

Sejarah sudah menunjukkan bahwa ada kalanya perempuan mempunyai kedudukan yang lebih tinggi daripada lakilaki karena aspek selain gender: misalnya, di Hindia Belanda pada awal abad kedua puluh dikenal tiga tingkat (atau derajat) dalam hierarki sosial: orang Belanda sebagai pihak kolonial, lalu orang Timur Asing, lalu orang pribumi. Dalam sistem tersebut perempuan Belanda mempunyai kekuasaan dan kedudukan yang lebih kuat daripada laki-laki pribumi. Perempuan Belanda mendapatkan kendaraan yang lebih bersih dan cepat, pelayanan dari pemerintah yang lebih baik, hak untuk bersenang-senang di tempat yang eksklusif, dan fasilitas-fasilitas lain yang tidak mungkin diterima laki-laki pribumi. Selain kedudukan etnis, masih dimungkinkan adanya peran aspek lain, misalnya kekayaan, usia, status perkawinan, dan pekerjaan.

Kedudukan kajian feminis dalam ranah hierarki kekuasaan, cerita pendek (cerpen) Agus Noor yang berjudul "BH" akan dikaji. Karya ini diterbitkan dalam koran Bernas pada tahun 1991 dan dimuat kembali dalam kumpulan cerpen yang berjudul Bapak Presiden yang Terhormat pada tahun 2000. Cerita ini mengisahkan seputar Rukmini, seorang pemudi yang menyadari bahwa kutangnya mulai meraba-raba payudaranya setiap kali ia memakainya. Setelah beberapa lama ia tidak mengenakan kutang dan mulai merasa lebih bebas. Namun, pada ulang tahunnya yang kedua puluh dua, ia menerima kado yang berisi lima kutang, dan akhirnya ia dibunuh oleh kutangnya itu di tengah ratusan mata merah.

Kalau dibaca secara harifiah, cerita ini tidak mungkin terjadi. Tidak ada kutang yang dapat meraba-raba dada perempuan seakan mempunyai tangan sendiri. Agus Noor dinyatakan kerap '"mem-fiksi-kan' sederet fakta sosial” (Arcana, 2011: 188). Pernyataan ini, bersama dengan peranan perempuan yang menonjol di dalam " $\mathrm{BH}^{\prime}$ dimana cerita yang tidak memiliki tokoh lakilaki yang muncul secara eksplisit menjadi dasar pemilihan cerpen ini sebagai bahan kajian. Hendak dikaji apakah fenomena sosial yang "di-fiksi-kan" dalam karya ini, jika ada, dalam kaitannya dengan feminisme. Selebihnya, akan ditemukan sejauh manakah 
fenomena sosial itu dicerminkan dalam karya.

Karya sastra dinilai oleh Lukács (dikutip dalam Makaryk, 1993: 410) memiliki sifat reflektif terhadap (mencerminkan) kenyataan sosial, meskipun tidak selalu secara langsung. Apa yang berada di lingkungan pengarang, yang ikut membentuk pengarang dan menjadi hal yang didukung atau ditolak olehnya. Karena itu, untuk cara yang terbaik untuk benar-benar memahami suatu karya sastra ialah memahami konteks sosiobudayanya. Paham ini yang digunakan untuk mencari kenyataan sosial yang dicerminkan dalam cerpen "BH". Namun, untuk lebih memahami kenyataan sosial itu harus dipahami dulu konstruksi gender dan sosial pada pemerintahan Soeharto, yaitu mereka yang dipertua(n)kan dan "anakisme".

Dalam tesis majisternya, Julia Suryakusuma meminjam konsep ibuisme dari Madelon Djajadiningrat, yang digunakan (dengan beberapa konsep dan model lain) untuk menjelaskan cara pemerintah Suharto membentuk pengertian perempuan secara sosial selama Orde Baru. Istilah ibuisme ini diartikan oleh Suryakusuma bukan hanya sebatas seorang perempuan (ibu) diperkenankan untuk melakukan apa saja untuk kepentingan "keluarga"-nya (keluarga, anak buah, karyawan, dan seterusnya, tetapi pada perempuan siapa pun yang memegang kekuasaan melalui keahlian professional, kekayaan, dan usia (Suryakusuma, 2011: 3). Dalam konteks konstruksi sosial Orde Baru, "ibu" sebagai tokoh yang memiliki kekuasaan ditempati Suryakusuma di bawah kekuasaan "bapak", laki-laki yang memiliki kekuasaan karena azas ekonomi, status sosial, usia, dan sebagainya yang menjadi lebih kuat karena budaya patriarki. Bapak menjadi sumber utama kekuasaan, dengan ibu sebagai mediator (Suryakusuma, 2011: 10).

Negara, menurut Orde Baru, dibangun atas azas kekeluargaan, dengan Ibu Negara dan Bapak Presiden yang sama-sama memegang kekuasaan, dan Ibu Negara menjadi mediator kekuasaan Bapak
Presiden. Namun, kekuasaan ini menjadi tidak berguna apabila tidak ada pihak untuk dikuasai; kekuasaan tanpa objek penguasaan hanyalah kekuasaan semu. Dalam suatu konstruksi keluarga, terutama keluarga dalam budaya Jawa yang menjadi salah satu landasan paling berpengaruh dalam konstruksi "bapak-ibuisme" ini, pihak yang dapat dikuasai oleh "bapak" dan "ibu" adalah anak. Objek dari kekuasaan "bapak" dan "ibu" adalah "anak", yang dituntut untuk mengikuti apa saja yang diminta dan terus bersedia untuk dibentuk ulang oleh "bapak-ibu".

Disebabkan "bapak" dan "ibu" lebih tua daripada "anak" - baca, dinyatakan memiliki pengalaman yang lebih banyak dan status yang lebih tinggi-maka "bapakibu" dipertua(n)kan; mereka mendapatkan kekuasaan (menjadi "tuan") atas dasar usia dan pengalaman ("tua" tidaknya), yang berdasarkan hubungan dengan mereka yang diperanakkan (dijadikan "anak"). Perempuan pun dapat dipertua(n)kan, tetapi sekali lagi dalam konteks Orde Baru yang patriarkis ia tidak pernah menjadi "tuan" yang benarbenar memiliki kekuasaan; sebutan "tuan" digunakan terkhusus "bapak", sementara "ibu" tetap menjadi mediator. "Anak" sendiri bukanlah suatu paham monolit, yang kesemuanya memiliki kedudukan yang sama. "Anak" ada yang perempuan dan ada yang laki-laki, dan kedua pihak ini mempunyai kedudukan yang berbeda dalam keluarga. Yang laki-laki cenderung diberi kebebasan lebih tinggi, sementara yang perempuan kerap dituntut untuk lebih taat pada orang tua, menjadi "anak" yang lebih teratur.

Sebagai "anak" dari "bapak-ibu", pihak yang dikuasai, diarahkan, dan dibentuk oleh mereka yang dipertua(n)kan dinilai layak dihukum atas pelanggaran yang dinyatakan telah terjadi. "Anak" durhaka, seperti dalam cerita rakyat Malin Kundang, akan mendapatkan kutukan dari "bapakibu". Ini tidak berarti bahwa mereka yang diperanakkan ini selalu akan terkalahkan oleh hegemoni yang muncul dari "bapak" 
dan "ibu". "Anak", meski dinyatakan mesti sudi menerima apa saja yang diperbuat oleh "bapak-ibu", akan merasa tertekan oleh hegemoni yang dipandang merugikan dirinya, dan akan melakukan resistensi untuk menjadikan dirinya sebagai subjek yang berkuasa. Ia bukan hanya melakukan resistensi melalui kekerasan fisik; hal tersebut akan cepat dihukum oleh "bapakibu". Yang dikuasai dapat melarikan diri ke luar kekuasaan "bapak-ibu", menolak, mengeluh, mengomel, atau mengubah gaya busana dan pembawaannya untuk melakukan resistensi dan membuktikan bahwa dirinya tidak "anak". Meskipun dihukum, lama-kelamaan "bapak" dan "ibu" akan melakukan perubahan sebagai strategi untuk memberlangsungkan kekuasaannya. "Anak" menjadi tenang, dan merasa bahwa ada perubahan, tetapi ia tidak benar-benar memiliki kekuasaan sehingga ia dipertua(n) kan oleh orang lain lagi; "bapak-ibu" masih memiliki kekuasaan atas dirinya, yang terwujud antara lain dengan pembentukan identitasnya.

Hubungan kekuasaan antara mereka yang dipertua(n)kan dan mereka yang diperanakkan digambarkan di bawah. Anak panah hitam tebal menggambarkan kekuasaan mutlak, sementara anak panah hitam yang terpatah menggambarkan kekuasaan yang diperoleh sebagai moderator. Anak panah titik berantai menggambarkan usaha resistensi yang, meskipun mungkin membawa perubahan, tidak akan mampu membalikkan hubungan hierarki.

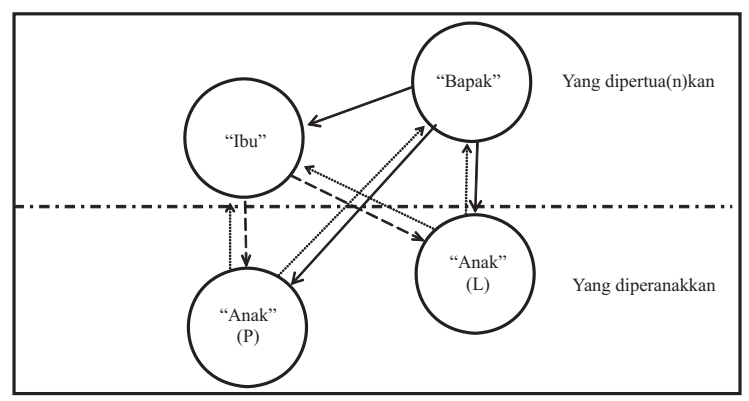

Metode yang digunakan dalam penelitian ini ialah metode kualitatif yang disajikan secara deskriptif. Analisis dilakukan secara intertekstual: teks " $\mathrm{BH}$ " dibaca lalu dikaitkan teks lain, yang di sini merupakan konteks sosial, baik konteks sosial Indonesia yang terdapat pada Orde Baru maupun konteks sosial tradisi Jawa yang telah melatarbelakangi Agus Noor.

\section{PEMBAHASAN \\ Alur Cerita}

Rukmini seorang pemudi modern, yang seakan bebas dari pengaruh laki-laki. Ia bukan orang bodoh, bukan juga orang yang tidak mandiri. Ia merasakan diri tidak tergantung pada laki-laki untuk memenuhi kebutuhan hidupnya. Justru ia "lincah, penuh bakat, dan letupan-letupan kreativitas" (Noor, 2000: 190), seorang perempuan yang bisa mengembara ke tengah alam dan seakan membuat keputusan atas tubuhnya sendiri. Sebagaimana mestinya perempuan modern, ia pun sudah menempuh pendidikan tinggi.

Namun, ia tetap mengalami keganjilan karena kutangnya. Setiap kali ia merasa "buah dadanya diremas-remas, seperti ada sepasang tangan yang dengan ganas menggagahinya" (Noor, 2000: 189). Ia mempertanyakan soal ini, dan semakin lama menjadi tidak senang akan hal yang menimpa dirinya. Ketika ia bertanya kepada ibu angkatnya, Tante Tien, Rukmini justru ditertawakan karena hal ini, dinyatakan "sedang mengajak Tante bergurau" (Noor, 2000: 190). Akhirnya Rukmini menjadi bimbang, lalu mengambil keputusan untuk tidak mengenakan kutang lagi. Ia merasa lebih percaya diri, dan Tante Tien menyatakan bahwa ia membuktikan kalau ia "berani", sesuatu yang diperlukan buat karier. Namun, akhirnya Rukmini terbunuh oleh kutang yang diterima saat ulang tahunnya; lima buah kutang itu masuk ke dalam mulutnya, sehingga ia tercekik.

\section{Kutang sebagai Simbol Hegemoni}

Kutang jelas menjadi persoalan di sini. Alat pakaian ini, yang kerap dianggap sebagai simbol keperempuanan, bukanlah hal yang alamiah. Tidak ada perempuan yang lahir dengan memakai kutang, dan dalam budaya tertentu misalnya Bali tradisional 
(Gambar 1) memakai kutang bukanlah kewajiban. Kutang juga bukanlah pakaian yang nyaman. Dalam konteks modern ia dapat dibentuk dari kawat, yang dapat menusuk dada orang yang memakainya. Kutang mungkin kurang pas, sering lepas, atau sering terbuka. Karena itu, Sally Weale (2000) dari The Guardian menulis bahwa "bras are at best uncomfortable; at worst they can be instruments of torture." ("kutang memang kurang nyaman; kalau kutangnya tidak baik, ia bahkan menjadi alat penyiksaan").

Mengapa mesti perempuan berkutang? Dilihat dari sejarahnya, penutupan payudara menjadi bagian tubuh yang berkembang secara alamiah yang dilakukan atas desakan sosial. Mereka yang dipertua(n)kan mengajar kelompok-kelompok yang tidak mengetahui soal kutang, misalkan anak atau yang diperanakkan, bahwa perempuan mesti memakai pakaian tersebut. Dalam konteks Bali, payudara lama-kelamaan menjadi hal yang tabu, benda hina yang harus ditutupi, karena pengaruh budaya Islam (terutama dari Jawa dan Melayu) serta Eropa yang dibawakan oleh penguasa kolonial patriarkis (Wiener, 2005: 76-77); kutang dibawa masuk ke dalam budaya Bali oleh mereka yang dipertua(n)kan. Sementara, dalam budaya Jawa, kebudayaan menutupi payudara diturunkan dari sultan dan raja-lakilaki semua, dan semuanya dalam posisi kekuasaan. Sampai sekarang kutang masih umum dikenakan. Wanita dituntut oleh masyarakat dan budaya setempat untuk memakai kutang supaya menyesuaikan diri dengan tata krama.

Karena kutang yang tidak nyaman ini menjadi kewajiban atas dasar desakan mereka yang dipertua(n)kan, ia sudah menjadi salah satu simbol opresi perempuan menurut pandangan feminis yang mulai berkembang, setidaknya, pada tahun 1968. Pada tahun itu, satu kelompok feminis di Amerika Serikat melakukan protes massal terhadap Miss America Pageant, suatu kontes kecantikan. Kelompok ini melemparkan sejumlah jenis pakaian yang dinilai terkhusus untuk perempuan termasuk kutang, sepatu hak tinggi, dan korset ke dalam tong sampah sebagai pembuangan simbolis terhadap "pembudakan" perempuan oleh kaum patriarkis, mereka yang dipertua(n) kan. Dalam media massa mereka dijuluki "bra-burners" (pembakar kutang) karena mempunyai minat membakar pakaian tersebut dan asosiasi kutang dengan opresi menjadi lebih terkenal (Carlisle and Golson, 2008: 160). Sebagai tanggapan atas pandangan tersebut, ada perempuan yang mulai tidak mengenakan kutang sebagai cara untuk menyatakan bahwa mereka melepaskan diri dari opresi. Layak-tidaknya nama ini tidak akan dibahas secara mendetail di sini. Pihak yang satu menyatakan bahwa nama ini diciptakan agar para feminis nampak konyol, sementara pihak lain menyatakan bahwa "bra-burning feminist" dimaksud untuk menyamakan protes feminis dengan protes anti-wajib militer (wamil), yang membakar kartu panggilan wamil.

Hal yang sama dapat dibaca dari perbuatan Rukmini dalam "BH". Ia mulai menyadari bahwa ia dijadikan seperti umpan untuk laki-laki yang dipertua(n) kan dan bersifat kasar, yang menggunakan kutang sebagai alat subjugasi perempuan; laki-laki seperti ini menyatakannya bahwa payudara adalah benda yang hina, tapi masih senang meraba-rabanya. Akhirnya Rukmini memilih untuk membebaskan payudaranya dari "belenggu" kutang, dan secara simbolik menolak kekuasaan mereka yang dipertua(n) kan. Ia dipuji untuk keberaniannya itu, dipuji karena melawan sesuatu yang tidak terlihat tetapi masih mampu menggagahinya. Namun, akhirnya Rukmini tidak mampu melawan kekuatan yang dipertua(n)kan yang sudah mengakar. Ia sebagai individu dibunuh oleh kekuatan itu, dan tidaklah ia dapat membebaskan diri dari kutang.

\section{Yang Dipertua(n)kan}

Kutang bukan satu-satunya masalah Rukmini yang membatasi kebebasannya sebagai individu. Tanpa disadarinya, Rukmini juga dibatasi oleh hierarki usia yang berlaku di dalam masyarakat 
Indonesia. Menurut "BH", Rukmini hendak memberontak kalau dipaksa memakai kutang, langsung melepaskannya dan membuang jauh. Namun, begitu ia merasa Tante Tien, perempuan yang dipertua(n) kan, menganggap Rukmini "bergurau", ia menjadi meragukan pengalaman sendiri. Karena dinyatakan bergurau, alias tidak berbicara secara serius ataupun jujur mengenai masalah yang dihadapinya, Rukmini harus mempertanyakan apakah memang ada masalah, apakah memang kutang dapat meremas-remas payudara. Karena jawabannya, menurut Rukmini, "iya", ia menjadi gundah. Rukmini akhirnya mengambil keputusan bahwa ia harus melepaskan kutangnya untuk membebaskan diri; dukungan Tante Tien dalam keputusan ini main peran juga. Tante Tien membantu Rukmini menjadi semangat, sehingga ia bisa menentang kebiasaan setempat. Perilaku Rukmini masih patuh pada Tante Tien, dan ia mendapatkan semangat kalau merasa bahwa dirinya didukung oleh orang yang dipertua(n)kan itu.

Dalam budaya Jawa, orang yang lebih tua atau menduduki posisi yang diberi pertanggungjawaban dianggap sangat layak dihormati, atau pêpundhèn (tempat menaruh hormat yang sangat besar). Orang tua dan orang yang lebih tua harus didengarkan dan diperhatikan, harus dipatuhi, oleh orang muda, seperti halnya Tante Tien dan Rukmini. Orang yang lebih tua bahkan tidak layak dinyatakan salah atau tidak sopan, sehingga hampir tidak dapat diganggu gugat; misalnya, anak boleh dinyatakan "kurang ajar", tetapi sebutan sedemikian untuk orang yang lebih tua tidak diperkenankan.

\section{"BH" dalam Konteks Sosial Orde Baru dan Tradisi Jawa}

Sejarah kutang dalam masyarakat yang digambarkan secara garis besar di atas sudah diketahui oleh Agus Noor, selaku kritikus sosial yang mengamati hak perempuan dan bahkan menulis naskah mengenai perempuan-perempuan yang berkuasa di belakang para pemimpin laki-laki
(Christianto, 2012). Bukan tidak mungkin ia mengambil sudut pandang feminis, yang menolak kekuasaan patriarkis dalam konstruksi sosial, saat menulis " $\mathrm{BH}^{\prime}$. Bahkan bisa terjadi ia, sebagai orang Jawa, masih dibatasi oleh budaya mempertua(n)kan mereka yang lebih dewasa, sehingga dapat menyatakan bahwa orang-orang seperti ini tidak dapat bersalah.

Namun, penjelasan di atas masih menyisakan pertanyaan yang tidak mampu ia jawab. Siapakah Tante Tien sebenarnya? Mengapa mesti Rukmini mati dengan karena sesak nafas, dicekik oleh kutangnya, bukan karena dicekik oleh tali pengikatnya? Apa kaitan mata merah dengan kutang? Ternyata penjelasan di atas masih belum dapat menyampaikan maksud penulis secara tepat. Masih ada maksud yang tersembunyi di belakang masalah kekuasaan perempuan atas tubuhnya yang sudah dijelaskan di atas, dan kelompok muda yang harus patuh pada orang tua. Hal ini ditandai dengan nama tokoh Tante Tien, yang mengantarkan pembaca pada hubungan antara yang dipertua(n)kan dan yang diperanakkan di luar karya.

Saat cerita ini ditulis pada tahun 1991 (Noor, 2000: 194), nama "Tien" biasanya merujuk pada Siti Hartinah, yang akrab dipanggil Ibu Tien. Karena Ibu Tien adalah istri dari Presiden Suharto, selaku seorang "Ibu" yang memediasi kekuasaan suaminya ia tidak dapat dilepaskan dari halnya pemerintahan Orde Baru; hubungan asosiasi jelas di sini. Saat cerpen ini ditulis, Ibu Tien dinilai sangat dekat dengan kekuasaan Suharto; menurut sejarawan Ong Hok Ham, Ibu Tien telah menerima "wahyu" yang membuat suaminya mampu menguasai Indonesia selama 32 tahun, sehingga ketika ia meninggal Suharto tidak dapat mempertahankan kekuasaan (dikutip dalam Mydans, 2001: A3). Selain itu, pengamat politik beranggapan bahwa Ibu Tien menjadi salah satu koruptor terbesar selama pemerintahan Suharto, karena mendapatkan potongan dari setiap transaksi. Hal ini begitu terkenal sehingga Ibu Tien diberi julukan 
"Ibu Tien Persen". Yayasan-yayasan yang didirikannya, seperti yayasan Dharmais, juga dianggap sudah mengorupsi banyak uang, dan anak-anak Ibu Tien dengan Suharto menjadi pemimpin (sekaligus koruptor) di banyak tempat karena kerabat keluarga.

Pandangan masyarakat Indonesia pada saat Suharto pertama kali menjabat sebagai presiden, ketika ia pertama kali dipertua(n) kan, tidak seperti itu. Pemerintahan Suharto disambut baik sebagai ganti pimpinan "bapak proklamator" Sukarno. Ketika Indonesia tertimpa inflasi yang sangat tinggi, yang bahkan mencapai 500 persen per tahun (Ricklefs, 1993: 280), orang awamseperti halnya keluarga Rukmini-hidup dalam kemiskinan dan kelaparan. Sekolah pun sedikit yang bisa tamat. Namun, di bawah Suharto, pada akhir tahun 1960an, sejumlah program reformasi politik dan ekonomi dimulai. Akhirnya ekonomi Indonesia menjadi lebih kuat dan inflasi dapat dikendalikan. Pendidikan juga dibuka secara lebih luas. Sekolahan-sekolahan dan universitas-universitas didirikan dalam jumlah yang banyak; misalnya, antara tahun 1970 dan 1990, jumlah perguruan tinggi naik dari 450 menjadi 900, sementara jumlah mahasiswa melejit, dari 237,000 menjadi 1.5 juta (Kuipers, 2011: 152).

Dalam propaganda yang disalurkan sistem pendidikan baru itu, masyarakat Indonesia diselamatkan dari kemiskinan oleh Suharto seorang diri; usaha ini merupakan pemeranakan masyarakat Indonesia, meski dinyatakan sebagai hal yang menguntungkan masyarakat umum. Seperti halnya Tante Tien yang telah memungkinkan keluarga Rukmini maju secara ekonomi dan pendidikan, di awal-awal Presiden Suharto dianggap masyarakat Indonesia yang diperanakkan ini sebagai penyelamat. Sampai awal tahun 1970-an ia jarang diganggu gugat.

Selain nama Tien yang merujuk pada Ibu Tien dan, akibatnya, pemerintahan Suharto, kata "Tante" pun menjadi lambang. Dalam budaya Jawa, yang sudah diamati Agus Noor sejak kecil, istilah "Tante" sering digunakan sebagai sebutan untuk seorang perempuan dari suku Tionghoa yang lebih tua, sementara orang Jawa kerap disebut "Ibu" atau "Bu". Karena itu, dapat disimpulkan bahwa Tante Tien ini merupakan orang keturunan Tionghoa. Di masa pimpinan Suharto, sejumlah orang Tionghoa memiliki kekuatan ekonomi yang sangat besar. Ada mereka yang memimpin sejumlah perusahaan besar, seperti Bob Hasan (kayu) dan Sudono Salim (perbankan), yang menjadi miliarder. Orang Tionghoa kaya seperti ini, yang disebut media sebagai konglomerat, mempunyai hubungan erat dengan Presiden Suharto. Mereka banyak memberikan uang kepada yayasan-yayasan yang didirikan Ibu Tien (meski belum tentu ikhlas). Akibatnya, mereka juga dapat mengarahkan kebijakan pemerintah dan mengambil keuntungan dari pengarahan tersebut; mereka menjadi orangorang yang dipertua(n)kan karena kekayaan mereka itu, meskipun tidak setingkat Suharto. Akan tetapi, kekuasaan yang dibeli itu, konglomerat dinilai oleh rakyat biasa yang diperanakkan sebagai perusak bangsa. Akhirnya, rakyat mulai menyamakan orang Tionghoa dengan koruptor (Purdey, 2006: 22), biarpun kenyataannya tidak semua orang Tionghoa seperti itu.

Nama Rukmini juga mempunyai arti tersendiri, yang merujuk pada salah satu tokoh dalam Purana, tulisan-tulisan agama Hindu yang sudah ratusan tahun dikenal di Pulau Jawa. Rukmini adalah salah satu istri Kresna, avatar dari Visnu. Sifat Rukmini dapat ditinjau dari Tulabharam, salah satu cerita mengenai hubungan antara Rukmini dan Kresna. Menurut Rao (2006: 118-119), suatu hari ada seorang pengemis yang datang ke Kresna dan meminta sumbangan yang beratnya sama dengan beratnya Kresna. Satyabama, istri lain dari Kresna, mengumpulkan semua emas dan permata yang dimilikinya, tetapi itu tidak cukup; beratnya masih kurang. Akan tetapi, setelah Rukmini memetik daun tulasi (Ocimum tenuiflorum) dari pohon kesayangan Kresna yang sudah lama ditanam Rukmini dan menempatkan daun tersebut di atas timbangan. 
Tanaman ini dianggap suci dalam agama Hindu (Vimalananda, Krishnakumar dan Selven, 2004: 51). Ternyata, satu daun tulasi yang ditanam dengan penuh cinta dan disumbangkan dengan ikhlas. Beratnya melebihi berat semua emas dan permata yang telah dikumpulkan. Dengan demikian, dapat dilihat bahwa Rukmini adalah orang yang mengetahui bahwa ada hal-hal yang lebih penting daripada harta. Namun, ia tetaplah orang yang memiliki kedudukan lebih rendah; selain harus mematuhi suami dan menjaganya dengan mengorbankan waktunya sendiri, Rukmini harus memenuhi permintaan tamunya.

Rukmini memang tidak melambangkan seorang tokoh masyarakat tertentu. Namun, berdasarkan ciri tokoh Rukmini dari Tulabharam serta pengertian tokoh historis yang dilambangkan oleh tokoh Tante Tien yang sudah diuraikan di atas, yang bertentangan dengan sifat Rukmini dalam " $\mathrm{BH}$ ", dapat disimpulkan jenis orang yang dilambangkan oleh Rukmini. Berdasarkan sifat tokoh Rukmini dalam cerita Hindu, dapat dianggap bahwa tokoh Rukmini dalam " $\mathrm{BH}$ " melambangkan orang(-orang) yang mempunyai cinta tulus yang tidak menganggap nilai uang sebagai hal yang mutlak. Orang-orang seperti ini menduduki posisi yang lebih lemah daripada mereka yang dipertua(n)kan. Sementara, dari kehadiran tokoh Tante Tien diketahui bahwa ada pesan politik, yang berkaitan dengan negara dan orang-orang yang dipertua(n) kan.

Dari kedua hal tersebut, dapat dipahami bahwa isu yang diangkat di sini bukanlah hanya pembatasan perempuan oleh mereka yang dipertua(n)kan, yang mewajibkan ia memakai kutang (biarpun masih ada pesan itu), tetapi pembatasan orang yang tulus mencintai tanah air oleh pemerintahan Suharto, terutama melalui penyensoran. Peran penyensoran ini, yaitu membuntut kemampuan orang untuk bebas berpendapat, menjadi jelas ketika Rukmini mati lantaran mulutnya dipenuhi lima buah kutang sehingga tidak bisa bernafas; alat yang digunakannya untuk menyampaikan pendapat ditutup oleh simbol represi, sehingga segala harapan untuk masa depan mati sebelum saatnya.

Penyensoran menjadi masalah yang cukup besar selama pemerintahan Suharto, seperti pada masa Sukarno sebelumnya. Selama pemerintahan Suharto, penyensoran terhadap pers sudah menjadi hal biasa. Surat kabar dan majalah diwajibkan mendapatkan Surat Izin Usaha Penerbitan Pers (SIUPS) dari Departemen Penerangan, dan yang tidak mendapatkan SIUPS-atau yang SIUPSnya dicabut-dilarang beredar; akibatnya, pemerintah dapat menutupi instansi pers dengan mudah. Setelah Peristiwa Malari pada tahun 1974, misalnya, ada dua belas terbitan berkala yang ditutup oleh pemerintahan, dan pempimpinnya dipenjarakan tanpa diadili, karena dinilai telah melakukan usaha subversi dengan laporan beritanya (Hill, 1994: 37-38). Bahkan sampai tahun 1990-an penyensoran masih terjadi; pada tahun 1994 tiga majalah besar, termasuk Tempo, ditutup paksa oleh pemerintah (Sen dan Hill, 2006: 54). Ada pula orang yang "dihilangkan" dan bahkan dibunuh secara terang-terangan, supaya mereka tidak dapat mengganggu status quo yang sudah ditetapkan pemerintah.

Usaha-usaha penyensoran ini dapat dilihat sebagai usaha mereka yang dipertua(n) kan untuk melestarikan kekuasaan mereka. Karena terjadi penyensoran ini, akhirnya banyak dari mereka yang diperanakkan menjadi takut untuk berbicara. Masyarakat yang hendak berbicara secara bebas seakan selalu diamati oleh pemerintah (melalui tetangga atau prajurit, antara lain). Kalau ketahuan ada seseorang yang sudah dianggap terlalu berani, maka orang itu akan menemukan maut, sebagaimana sudah dijelaskan di atas. Keadaan menjadi sangat was-was, dan kritik-kritik harus dilakukan secara tersembunyi. Kehidupan menjadi seakan ada sejumlah mata mengerikan (dalam cerita, merah) yang bersembunyi di dalam bayang-bayang, melihat dan mencari setiap kesalahan supaya dapat merusak kehidupan incarannya. Masyarakat harus 
hidup dalam ketakutan pada "mata yang bersorot mendakwa," seperti dalam cerita "BH".

Seperti halnya kutang menutupi bagian tubuh yang dianggap tabu untuk dilihat dan dipegang oleh mereka yang dipertua(n) kan di Jawa, maka pendapat dan kenyataan yang dinilai membahayakan ditutupi oleh sensor. Pernyataan-pernyataan sedemikian rupa dicari pemerintah dengan susah payah, seakan memasang mata dan telinga di setiap tempat. Namun, sebenarnya payudara menghasilkan susu dan karena itu sangatlah penting untuk pertumbuhan seorang anak, sehingga ketika ditutupi kutang anak tidak dapat minum dan berkembang. Demikian pula kebebasan berpendapat, yang menghasilkan ide-ide yang mungkin akan digunakan untuk memerdekakan mereka yang diperanakkan dari penindasan. sehingga ketika terjadi penyensoran rakyat tidak dapat berkembang dengan semestinya.

Cerita ini dapat dilihat sebagai suatu alegori, sehingga kalau dibongkar berbunyi sebagaimana berikut ini. Ketika orang Indonesia yang nasionalis sudah menjelang dewasa, ia merasa beratnya penyensoran terhadap dirinya. Ia memahami bahwa pemerintah menekan-nekan dan menggagahi orang yang lebih mencintai negara daripada uang, orang yang berani melawan kepentingan pemerintah. Orang Indonesia ini hendak membebaskan diri dari "kutang" opresi, dan mengaduh pada orang yang dipercaya karena dianggap penyelamatnya dahulu kala.

Orang-orang yang dipercaya ini, keluarga Suharto, menyatakan bahwa tekanan semacam itu mustahil, dan menyarankan untuk tidak merasa terganggu. Akhirnya, setelah merenungkan keadaannya, orang yang tulus mencintai negara ini mengambil keputusan bahwa keluarga Suharto tidak ada salahnya, tetapi penyensoran tidak boleh dibiarkan terus-menerus. Orang ini melepaskan diri dari penyensoran, menjadi terkenal karena tidak dibelenggu oleh "kutang" dan dipuji keberaniannya yang dapat melejitkan karier. Akan tetapi, akhirnya penyensoran itu kembali dan lebih ganas daripada sebelumnya, sehingga orang nasionalis ini pun kena maut. Seperti halnya seorang feminis yang berusaha untuk mencari kebebasan menjadi seorang perempuan dalam budaya patriarkis, seorang nasionalis yang mencari keadilan akhirnya musnah karena kekuasaan yang lebih besar daripada dirinya sendiri.

Muncullah suatu pertanyaan: apakah ini berarti kajian feminis terhadap cerita " $\mathrm{BH}$ " tidak membawa hasil? Tentu tidak demikian. Dalam cerpen ini seorang perempuan merupakan anggota kelompok yang diutamakan oleh kajian feminis yang dibatasi oleh simbol represi mereka yang dipertua(n) kan yang bersifat patriarkis: Rukmini dengan kutangnya. Ini menjadi gambaran dari semua kelompok yang diperanakkan, baik karena alasan fisik, usia, maupun kemampuan ekonomi, yang dibatasi oleh penyensoran dari pihak yang dipertua(n)kan.

Perjuangan mereka memang tidak dapat dinyatakan secara eksplisit, mengingat banyaknya penyensoran pada tahun-tahun itu, sehingga harus dimunculkan dengan pendekatan yang lebih dapat diterima oleh pihak yang berkuasa agar dinilai tidak membahayakan status quo. Perjuangan perempuan di sini layak dipahami dalam konteks perjuangan sosial pada umumnya. Mengingat bahwa perjuangan perempuan untuk emansipasi tidak terlepas dari perjuangan masyarakat luas, selaku kelompok yang diperanakkan, usaha untuk mengubah status quo masih dimungkinkan. Pesan pesimis Agus Noor bahwa penyensoran dan opresi dari Orde Baru selalu membawa kematian sudah terbukti tidak benar; masih dimungkinkan adanya perbaikan.

Tujuh tahun setelah Agus Noor menulis "BH" Presiden Suharto sudah mengundurkan diri di tengah krisis ekonomi yang merosotkan nilai rupiah, dari Rp 2.682 per dolar AS pada tahun 1997 hingga puluhan ribu rupiah per-dolar AS pada pertengahan tahun 1998. Pada periode ini, terutama menjelang Mei 1998, kebebasan berpendapat menjadi kekuatan yang bahkan 
lebih besar dari kekuatan militer. Ketika mahasiswa-mahasiswi Universitas Gadjah Mada membakar boneka Suharto pada bulan Maret 1998, misalnya, kekuatan militer tidak mampu menghentikan prosesnya; mereka hanya dapat melarang publikasi foto peristiwa ini. Semakin lama kekuatan opresif semakin Suharto merosot, masyarakat tidak mendukungnya, dan pemimpin aparat serta pendukung politik meninggalkannya. Demonstrasi dan pendapat yang diutarakan secara bebas oleh jumlah orang yang jauh lebih banyak jumlahnya daripada aparat yang ditugaskan untuk menutupi suara "berbahaya" itu, sehingga pemegang kekuasaan merasakan diri dalam keadaan yang berbahaya. Akhirnya, Presiden Suharto terpaksa mengundurkan diri.

\section{"BH" Pasca-Orde Baru}

Selama masa pasca-Suharto muncul reformasi penyensoran dan pers melalui tindakan aktual dan kebijakan. Jumlah wartawan yang terbunuh saat menjalani tugasnya mulai berkurang, seperti juga halnya jumlah demonstrator yang tertembak mati. Diberlakukan UndangUndang Pers pada bulan September 1999 secara formal melindungi kebebasan pers, dan amandemen pada Undang-Undang Dasar melindungi (antara lain) kebebasan berpendapat. Sekarang jarang ada orang yang takut mengutarakan rasa tidak senang mengenai kebijakan pemerintah, misalnya, dan demonstrasi (mesti kerap direncanakan oposisi politik) dibiarkan terjadi, asal tidak ada unsur kekerasan. Menurut Freedom House, Indonesia kini merupakan salah satu negara Asia Tenggara dengan pers yang paling bebas (Freedom House, 2012). Namun, masih terjadi penyensoran yang didukung dengan kekerasan fisik: Sehabis Erwin Arnada menerbitkan Playboy Indonesia pada bulan April 2006, misalnya, terjadilah demonstrasi dan aksi kekerasan besarbesaran di bawah pimpinan Front Pembela Islam. Pada akhirnya, pemerintah membawa tuntutan hukum terhadap Erwin, dan ia dipenjarakan. Ada pula tuduhan defamasi dan penghujatan yang masih diluncurkan dan dipertahankan oleh pengadilan.

Jika ditarik lebih lanjut, peristiwaperistiwa yang terjadi sejak tahun 1998 menunjukkan bahwa kelompok yang diperanakkan tidak akan tertindas dalam bentuk yang sama untuk selamanya. Masih dimungkinkan adanya perubahan yang menguntungkan mereka, asalkan saja mereka siap bertindak. Mereka dapat berkembang secara dinamik, sehingga kelompok yang sebelumnya dipertua(n) kan akan diperanakkan dan sebaliknya. Demikian pula halnya perempuan, yang sampai sekarang belum dijamin haknya secara khusus (ataupun kesetaraannya dengan laki-laki) dalam Undang-Undang Dasar.

Di Indonesia sekarang masih banyak kasusyangbersangkutandengan pelanggaran hak perempuan. Representasi perempuan dalam badan negara masih kurang memadai dengan demografi Indonesia; belum tercapai, misalnya, 50 persen anggota DPR itu perempuan. Anak-anak perempuan masih diculik atau dijual oleh orang tuanya untuk menjadi pekerja seks komersial, baik di dalam ataupun di luar negeri. Perempuan yang sudah bukan perawan, baik yang lajang maupun yang janda, kerap diperlakukan sebagai manusia yang sudah rusak; mereka kerap susah menikah dan bisa dianggap sudah rusak dan tidak bernilai lagi. Perlunya perubahan sangat menonjol.

Berbeda dengan akhir cerita " $\mathrm{BH}^{\prime}$ yang pesimis, dengan membalikkan hubungan feminisme dan perjuangan sosial lain oleh kelompok yang diperanakkan dari metonimi menjadi totum pro parte (keseluruhan untuk sebagian), muncul suatu harapan baru. Mengingat bahwa perubahan sosial luas muncul karena ada demonstrasi dan perlawanan secara massal, maka perjuangan feminis masih dapat membawa hasil, asal ada yang perjuangkan. Presiden Suharto sempat dijatuhkan oleh masyarakat, maka hubungan laki-laki dan perempuan yang lebih setara masih dapat tercapai. Namun, adanya pihak yang dipertua(n)kan dan yang diperanakkan 
selama ini tidak dapat dihapus; selalu ada keduanya.

\section{SIMPULAN}

Pada lapis atas, cerpen " $\mathrm{BH}$ " karya Agus Noor merupakan suatu kritik atas pembatasan perempuan muda sebagai pihak perempuan yang diperanakkan oleh konstruksi sosial di sekitarnya yang mewajibkannya mengenakan kutang untuk menutupi payudara. Namun, kalau cerita ini dilihat dalam konteks masyarakat yang telah melahirkannya, yaitu Indonesia pada tahun 1990-an, dengan pemerintahan Suharto yang sudah tidak dihormati penulis dan pers sebagai "bapak" karena tindakan represifnya, " $\mathrm{BH}$ " menjadi suatu alegori mengenai orang yang mencintai tanah air yang merasa direpresi oleh kekuatan pihak yang dipertua(n)kan yang sukar dilawan. Hal ini menjadi semakin jelas dengan sejumlah tanda reflektif yang ditawarkan dalam teks, antara lain nama tokoh dan peranan mereka.

Hal ini menampakkan kenyataan bahwa perjuangan feminisme pada dasarnya tidak dapat dipisahkan dari perjuangan hak kaum tertindas lain. Perempuan bukanlah satu-satunya kaum yang diperanakkan oleh mereka yang dipertua(n)kan (kaum yang berkuasa). Di Indonesia modern, misalnya, orang muda ditindas orang tua, orang asing ditindas orang pribumi, orang miskin ditindas orang kaya, dan orang di luar pulau Jawa ditindas oleh penduduk pulau Jawa; dalam setiap hubungan kekuasaan ini dapat dilihat paham mereka yang dipertua(n)kan yang memperanakkan mereka yang tidak berkuasa. Dinyatakanlah dalam bahasa Inggris, "no one is free when others are oppressed." Pesan ini berlaku sebagai panggilan untuk semua pembaca, supaya dapat menolak penindasan dari pemerintahan.

Bisa terjadi penggunaan teknik seperti yang digunakan Agus Noor dalam " $\mathrm{BH}$ " bukanlah hal yang unik. Karya-karya sastra lain, yang memperlihatkan perempuan yang ditindas, diperkosa, dibatasi, dan diobjektifikasi dapat dibaca sebagai metonimi dinamika hubungan mereka yang dipertua(n) kan dan mereka yang diperanakkan yang lebih luas. Alhasil, ini dapat mengemukakan resistensi yang lebih luas, yang kerap tidak dapat dinyatakan secara explisit karena ketakutan pada hukuman dari mereka yang berkuasa. Dengan demikian, kritik sosial tajam yang diungkapkan di dalam masyarakat yang diperanakkan dapat dijelaskan secara mendetail dengan melihat relasi-relasi antara kelompok-kelompok yang diperanakkan itu.

\section{DAFTAR PUSTAKA}

Arcana, P.F. 2011. Dodolit Dodolit Dodolibret. Jakarta: Kompas.

Carlisle, R.P. dan Golson, J.G, 2008. America in Revolt During the 1960s and 1970s. Santa Barbara: ABC-CLIO.

Christianto, D. 2012. “Agus Noor: Discipline and Good Writing" The Jakarta Post. Diunduh pada 18 Maret 2013 dari http://www.thejakartapost. com/news/2012/11/29/agusnoor-discipline-and-good-writing. html. Diarsipkan di http://www. webcitation.org/6FD1tjcEY.

Freedom House. 2012. Indonesia, freedomhouse.org. Diunduh pada 27 April 2013 dari http://www. freedomhouse.org/report/freedompress/2012/indonesia. Diarsipkan di http://www.webcitation.org/ 6GBhfmVv0.

Hill, D. 1994. The Press in New Order Indonesia, Jakarta: Equinox.

Kuipers, J. C. 2011. The Society and Its Environment Indonesia: A Country Study. Washington, D.C.: Federal Research Division, Library of Congress.

Makaryk, I. R. 1993. Encyclopedia Of Contemporary Literary Theory: Approaches, Scholars, Terms. Toronto: University of Toronto Press.

Mohanty, C.T. 1988. "Under Western Eyes: Feminist Scholarship and Colonial" Discourses, Feminist Review, No. 30, 61-88. 
Mydans, S. 2001. “Jakarta's Rulers Ever in Need of Ghostly Guidance New York." New York Times.

Noor, A. 2000. BH: Bapak Presiden yang Terhormat. Yogyakarta: Pustaka Pelajar.

Purdey, J. 2006. Anti-Chinese Violence in Indonesia, 1996-1999. Honolulu: University of Hawaii Press.

Qomariyah, U. 2011. "Citra Perempuan Kuasa dalam Perspektif Kritik Sastra Feminis Novel Perempuan Berkalung Sorban Karya Abidah El-Khalieqy." Lingua. Vol. 7, No. 2. Diunduh dari http://journal.unnes.ac.id/ nju/index.php/lingua/article / view/2052/2164.

Rao, S.R. 2006. Krishna. New Delhi: Orient Longman.

Ricklefs, M.C. 1993. A History of Modern Indonesia, ca. 1300 to the Present. London: MacMillan.

Rustapa, A.K. 1997. Gagasan tentang Wanita dalam Novel Layar Terkembang dan
Pada Sebuah Kapal. Jakarta: Balai Pustaka.

Sen, K. dan Hill, D. 2006. Media, Culture and Politics in Indonesia. Jakarta: Equinox.

Suryakusuma, J. 2011. State Ibuism: The Social Construction of Womanhood in New Order Indonesia, Jakarta: Komunitas Bambu.

Vimalananda, S; Krishnakumar, R; dan Selven, M. 2004. Why do We. Mumbai: Central Chinmaya Mission Trust.

Weale, S. 2000. "The Big Squeeze." The Guardian. Diunduh pada 17 Maret 2013 dari http://www.guardian. co.uk/world/2000/oct/31/gender. uk. Diarsipkan di http://www. webcitation.org/6FBKDgYf3.

Wiener, M. 2005. Breasts, (Un)dress, and, Modernist Desires in the Balinesetourist Encounter. Dirt, Undress, and Difference: Critical Perspectives on the Body's Surface. Indiana University Bloomington Press: . 